\title{
Killing time
}

An unexpected stay.

\section{John Gilbey}

The flight surgeon hummed distractedly, and tunelessly, as he prodded his way through my scan results.

"That's your problem - right there ..." he said proudly, conjuring a pair of images into the space between us while I struggled back into my coverall. "This one was 15 years ago - at the start of your last long run. The other one is today. See all that extra red? Nerve damage: around level 6 I'd say..."

"What the hell does that mean?" He watched me fumble with the fastenings and nodded to my hands. "It means, John, that you are grounded. No more Sleep for you, my friend. If I let you ship out again there is a pretty good chance you won't wake up. Sorry, that's just the way it is".

"But I'm contracted for a dozen more flights! You can't just dump me - I'm not 35 yet!"

"I can, and I will." He swung his chair closer to me. "Look, you've had a good run - but forget about being 35 . Your body has put up with..." he checked his notes, " 27 freezethaw cycles. That might even be a record - but it is killing you: slowly at the moment, abruptly if you risk another trip." He patted my knee with synthetic bonhomie. "Just relax for a few days, HR will be in touch."

Astrogators don't drink. I had to remind myself of that hourly for the next week as I wandered aimlessly around the unfamiliar city, pretending to do the tourist thing. Then I had a call, the Company wanted to see me.

The local headquarters building was right on the Skyport approach, close enough to feel the backwash from the orbital shuttles as I braced myself to walk into the foyer. The HR director was about my own - subjective - age, good-looking in a kooky way, and introduced herself as Lucy.

"We won't let you starve," was her opening gambit. "But I see that you traded most of your pension rights for cash some years ago." Flight crew don't need pensions - or so I'd thought at the time. I smiled in recollection, the lump sum had paid for some really wild rides - wrangling flaming dragons above frozen moons, that sort of thing.

"Your flight status has been permanently revoked - so your contract is void. Is there anything else you can do? I think we can exclude teaching - most of your qualifications are 60 years old, and the new ships are mostly autonomous anyway..."

I pondered this for a moment. "I write pretty good science fiction - that still ought to pay something."

She smiled - a real, non-corporate one. "I thought it might be you - both my parents were in the Service, and I read your stuff in Astro when I was a kid - I've still got copies somewhere. Here, I got you this ..." She handed me a flier: an advert for a writers' conference a month hence. She

space opera like this any more, and I'd advise you not to try. Here, for example, you describe the Centaurians as 'cruel and warlike'. Bad idea - they've chaired the Peace Congress for ten years straight. Call them 'warlike' in print and you'll get invited to a dinner celebrating their Warrior Caste - with an apple in your mouth... And here - the rather rampant alien sex, it's just ... so ... wrong. Sorry."

The others were no more hopeful. Despairing, I was about to drag my bruised ego back home when I spotted the free bar. Astrogators don't drink - but I'm not an astrogator any more. Nor a writer apparently.

Much later, I stumbled out onto the wide, empty, moonlit terrace overlooking the ocean. My spacer's mind tried painfully to orient itself as I looked up at the freakish dome of the sky. It was a while before I found Sol - tucked away insignificantly in an unfamiliar constellation. I gripped the cold glass railing while tears of delayed reaction and impotent fury dripped from my face.

There was someone behind me - if I was lucky, it was Security coming to throw me out. If not, it might be the Centaurians ... I turned abruptly, making Lucy jump and spill her drink.

"Sorry, I didn't think you'd come," I blurted in apology.

smiled again, shook my hand and held it for a moment. "I'd love to see a new story from you, I really would." I thanked her, promised to stay in touch, and left. I suddenly felt like her granddad.

The Company granted me a room and mess rights at the crew hostel - better, I was authorized for local travel and rode the rapid transit daily to the nearest beach. I worked on my tan and my novel simultaneously with my feet propped on a 'No Swimming' sign, and at the end of the month - after some critical input from Lucy — found myself striding confidently into the conference centre proudly clutching the requisite synopsis and first three chapters.

The first agent I spoke to let me down gently. "You have a good style - you write well - but ..." Here it comes, I thought. "It's grindingly archaic — no one publishes
She looked at the torn paper scattered at my feet and probably guessed the rest but I told her anyway. Taking my arm, she turned me back to face the rolling, phosphorescent sea. As we watched, a second moon rose slowly above the western horizon, casting an orange light over the breaking waves. Far across the bay, improbably massive sauropods began to broach wildly then crash back into the water in some complicated ritual.

Closer, the musky scent of alien flowers mixed dangerously with Lucy's perfume. Maybe - just maybe - this wasn't such a bad planet after all.

As a third moon lifted into the sky, Lucy leaned her head against my shoulder, slipped her fingers between mine and murmured: "Have you ever thought of writing a romance?"

John Gilbey is a gentleman and a scholar who lives in North Wales. 